\title{
Canada's Treatment of Non-Citizens through the Lens of the United Nations Individual Complaints Mechanisms
}

\author{
Le traitement de non-citoyens par le Canada du \\ point de vue des mécanismes onusiens de plaintes \\ émanant de particuliers
}

\author{
IDIL ATAK AND LORIELLE GIFFIN
}

\section{Abstract}

The United Nations (UN) human rights treaty bodies play an important role in defining the scope and the nature of non-citizens' rights. This article offers a critical overview of the UN human rights case law from 2008 to 2018 pertaining to non-citizens - notably undocumented migrants, refused asylum seekers, and permanent residents ordered deported - in Canada. It examines the jurisprudence of the three UN human rights treaty bodies recognized by Canada as having competence to receive and consider individual complaints — namely, the UN Human Rights Committee, the Committee against Torture, and the Committee on the Elimination of Discrimination against Women. The purpose of this examination is two-fold. First, it intends to foster a better understanding of the cases lodged by non-citizens before the UN human rights treaty bodies. The second aim is to explore the substantive

\section{Résumé}

Les organes créés en vertu d'instruments des Nations Unies (ONU) relatifs aux droits de la personne jouent un rôle important dans la définition de la portée et de la nature des droits de non-citoyens. Cet article offre un aperçu critique de la jurisprudence onusienne, entre 2008 et 2018 , en matière des droits de la personne des non-citoyens - notamment les migrants sans papiers, les demandeurs d'asile déboutés et les résidents permanents sujets à expulsion - se trouvant au Canada. Plus particulièrement, il examine la jurisprudence des trois comités relatifs aux droits de la personne que le Canada a reconnu comme compétents pour recevoir et examiner les plaintes individuelles, à savoir le Comité des droits de l'homme de l'ONU, le Comité contre la torture, et le Comité pour l'élimination de la discrimination à l'égard des femmes. Le but de cet examen est double. Premièrement, il vise à favoriser une meilleure compréhension

Idil Atak, Associate Professor, Department of Criminology, Ryerson University, Toronto, Canada (idil.atak@arts.ryerson.ca).

Lorielle Giffin, PhD candidate, University of Alberta, Edmonton, Canada (lgiffin@ryerson.ca). 
issues that the UN committees' jurisprudence on non-citizens reveals about Canada's immigration decision-making and enforcement. It is argued that some groups of non-citizens in Canada are at risk of being deported to persecution or hardship in violation of the nonrefoulement principle and Canada's international human rights obligations. The article illuminates several loopholes identified by the UN treaty bodies in Canada's immigration and refugee protection system that heighten the risk of refoulement.

Keywords: Canada; international human rights law; non-citizens; migrants; nonrefoulement; United Nations individual complaints mechanisms. des recours intentés par les non-citoyens devant les organes conventionnels des droits de la personne de l'ONU. Le deuxième objectif est d'explorer des questions de fond, révélées par la jurisprudence des comités de l'ONU en matière des noncitoyens, concernant le processus décisionnel et la mise en vigueur du système d'immigration canadien. Les auteures maintiennent que certains groupes de non-citoyens au Canada risquent d'être renvoyés vers des persécutions ou des épreuves, en violation du principe de non-refoulement et des obligations internationales du Canada en matière de droits de la personne. Cet article met en lumière plusieurs lacunes identifiées par les comités onusiens des droits de la personne dans le système canadien d'immigration et de protection des réfugiés, lacunes qui augmentent le risque de refoulement.

Mots-clés: Canada; droit international des droits de la personne; non-citoyens; migrants; non-refoulement; mécanismes onusiens de plaintes émanant de particuliers.

\section{INTRODUCTION}

Tn August 2018, the United Nations (UN) Human Rights Committee (HRC) ruled that Canada's denial of essential health care services to Nell Toussaint, an undocumented migrant from Grenada, violated her right to life. Noting that states cannot make a distinction, for the purposes of protecting the right to life, between legal and undocumented migrants, the HRC asked Canada to take all steps necessary to prevent similar violations in the future. ${ }^{1}$ As this case illustrates, in international law, a state's sovereign right to control the entry, residence, and expulsion of noncitizens $^{2}$ involves a duty to protect everyone under its jurisdiction. ${ }^{3}$ The UN human rights treaty bodies have been instrumental in defining the

1 Toussaint v Canada, Communication No 2348/2014 (30 August 2018) at para 11.7 [Toussaint].

2 Abdulaziz, Cabales and Balkandali v United Kingdom (1985), 7 EHRR 471.

${ }^{3}$ Island of Palmas (US v Netherlands), Hague Ct Rep 2d (Scott) 83 at 93 (Perm Ct Arb 1928); Singh $v$ Minister of Employment and Immigration, [1985] 1 SCR 177. 
scope and the nature of non-citizens' rights. Individual complaints mechanisms available under certain human rights treaties have played a particularly important role in this regard. ${ }^{4}$

This article offers a critical overview of the UN human rights case law pertaining to non-citizens ${ }^{5}$ in Canada from 2008 to 2018. It focuses on those complaints that intersect with the Immigration and Refugee Protection Act $(I R P A)^{6}$ and that are lodged by non-citizens, notably undocumented migrants, refused asylum seekers, and permanent residents ordered deported from Canada. Our analysis shows that the vast majority of the decisions adopted by the UN human rights treaty bodies in the past decade concern the rights and freedoms of non-citizens. As such, we illuminate significant issues with Canada's treatment of this population. More specifically, we suggest that Canada does not always meet its international obligations related to the non-refoulement principle, which prohibits the deportation of individuals to places where they may face persecution or a substantial risk of torture or similar abuse. ${ }^{7}$ The effectiveness of the domestic remedies available to non-citizens facing deportation and Canada's inconsistent compliance with the HRC's recommendations are other areas of concern explored in this article.

We examine the jurisprudence of the three UN human rights treaty bodies recognized by Canada as competent to receive and consider individual complaints - namely, the HRC, the Committee against Torture (CAT), and the Committee on the Elimination of Discrimination against Women

${ }^{4}$ Henry J Steiner, Philip Alston \& Ryan Goodman, International Human Rights in Context: Law, Politics, Morals, 3rd ed (New York: Oxford University Press, 2007) at 891-924; Christof Heyns \& Frans Viljoen, "The Impact of the United Nations Human Rights Treaties on the Domestic Law" (2001) 23:3 HRQ 483; Guy Goodwin-Gill \& Jane McAdam, The Refugee in International Law, 3rd ed (Oxford: Oxford University Press, 2007) at 285-354; Fernando M Marino Menendez, "Recent Jurisprudence of the United Nations Committee against Torture and the International Protection of Refugees" (2005) 34:1 Refugee Survey Quarterly 61; Jean-Yves Carlier \& Sylvie Saroléa, Droit des étrangers (Louvain-la-Neuve: Larcier, 2016).

${ }^{5}$ The term "non-citizen" refers to a foreign national who does not hold Canadian citizenship.

${ }^{6} \mathrm{SC} 2001$, c 27 [IRPA].

7 Convention Relating to the Status of Refugees, 28 July 1951, 189 UNTS $15^{\circ}$ (entered into force 22 April 1954), art 33(1) [Refugee Convention]; Convention against Torture and Other Cruel, Inhuman or Degrading Treatment or Punishment, 10 December 1984, 1465 UNTS 85 (entered into force 26 June 1987), art 3 [Convention against Torture]; International Covenant on Civil and Political Rights, 16 December 1966, 999 UNTS 171 (entered into force 23 March 1976), art 7 [ICCPR]; IRPA, supra note 6, s 115. Refugee Convention, ibid, art 33(1): "No Contracting State shall expel or return ('refouler') a refugee in any manner whatsoever to the frontiers of territories where his life or freedom would be threatened on account of his race, religion, nationality, membership of a particular social group or political opinion." 
(CEDAW Committee).$^{8}$ These bodies of independent experts are in charge of monitoring the implementation of the International Covenant on Civil and Political Rights (ICCPR) ${ }^{9}$ the Convention against Torture and Other Cruel, Inhumane or Degrading Treatment or Punishment (Convention against Torture), ${ }^{10}$ and the Convention on the Elimination of All Forms of Discrimination against Women $(C E D A W),{ }^{11}$ respectively. Individual complaints, known as communications, can be introduced by individuals ${ }^{12}$ subject to Canada's jurisdiction who claim to be victims of a violation of any of the rights set forth in the relevant treaty. ${ }^{13}$ Before considering any claims contained in a complaint, the UN committee determines whether or not the claim is admissible. ${ }^{14}$

8 These panels are composed of independent experts of recognized competence in human rights who are nominated and elected for fixed renewable terms by states parties.

${ }^{9}$ ICCPR, supra note 7 .

${ }^{10}$ Convention against Torture, supra note 7.

11 Convention on the Elimination of all Forms of Discrimination against Women, 18 December 1979, 1249 UNTS 13 (entered into force 3 September 1981) [CEDAW].

${ }^{12}$ We will refer to these individuals as "complainants." "Author" is the official term used in the UN treaty bodies' jurisprudence.

${ }^{13}$ States parties to the Convention against Torture, supra note 7, can declare that they recognize the competence of the Committee against Torture (CAT) to receive communications (art 22.1). Canada recognized the competence of the CAT on 13 November 1989. Optional Protocol to the International Covenant on Civil and Political Rights, 16 December 1966, 999 UNTS 302 (entered into force 23 March 1976) [OP-CCPR]; Optional Protocol to the Convention on the Elimination of all Forms of Discrimination against Women, 18 December 1979, 1249 UNTS 13 (entered into force 22 December 200o; accession by Canada on 18 October 2002) [OP-CEDAW]. On 3 December 2018, Canada acceded to the Optional Protocol to the Convention on the Rights of Persons with Disabilities, thereby accepting the individual complaints procedure under this treaty. However, our analysis does not cover this mechanism since there were not any complaints made against Canada under this convention as of March 2019 .

${ }^{14}$ Human Rights Committee Rules of Procedure, Doc CCPR/C/3/Rev.1 1 (9 January 2019), Rule 93. In order to be deemed admissible, a communication must satisfy certain requirements of the treaty under which it is submitted. A communication should not be anonymous or constitute an abuse of the right to submit a communication. OP-CCPR, supra note 13, art 3; Convention against Torture, supra note 7, art 22.2; OP-CEDAW, supra note 13 , arts $3,4.2 .(\mathrm{d})$. As well, the committee must establish that the matter is not being, and has not been, examined under another procedure of international investigation or settlement. OP-CCPR, supra note 13, art 5.2.(a); Convention against Torture, supra note 7, art 22.4. (a); OP-CEDAW, supra note 13, art 4.2.(a). The communication must also be compatible with the provisions of the treaty under which it is filed. The allegations must be sufficiently substantiated and not be manifestly ill founded. CEDAW, supra note 7, art 4.2.(c). Under the CEDAW, a communication can be deemed inadmissible if the facts of the communication occurred prior to the entry into force of the Optional Protocol for the state party. The exhaustion of all available domestic remedies is another main admissibility criterion. OP-CCPR, supra note 13, art 2; Convention against Torture, supra note 7, art 22.4(b); OP-CEDAW, supra note 13, art 4.1. 
If a communication is admissible, it considers its merits - that is, the substantive issues raised therein - before publishing its findings..$^{15}$

In providing a picture of the individual complaints filed against Canada by non-citizens before these UN human rights treaty bodies, our purpose is two-fold. First, we intend to foster a better understanding of the use of this supra-national recourse by non-citizens, including the nature of allegations made and the outcome of the complaints. We also discuss the various factors that may affect and enhance such recourse. Our second aim is to explore the substantive issues that the UN committees' jurisprudence on non-citizens reveals about Canada's immigration decision-making and enforcement. Our findings suggest that despite strong protections offered to migrants, refugee claimants, and other non-citizens in Canada, this population is still at risk of being deported to persecution or hardship in violation of Canada's international human rights obligations. Our analysis points to some important principles highlighted in the UN decisions to guide Canadian authorities in improving compliance with these principles and, more generally, the condition of non-citizens.

Research on this topic remains scarce in Canada. To date, most studies deal with the implementation and the influence of international human rights law on domestic laws and policies concerning non-citizens. For instance, Audrey Macklin ${ }^{16}$ as well as François Crépeau, Delphine Nakache, and Idil Atak ${ }^{17}$ have noted that international law is increasingly used to interpret the IRPA. They argue that the Immigration and Refugee Board of Canada (IRB), the administrative tribunal that is responsible for making decisions on immigration and refugee matters, refers to international human rights standards in order to determine whether a refugee claimant fears persecution. By contrast, Catherine Dauvergne has found that international law is relied on in an infinitesimally small number of court decisions, and non-citizens in Canada often do not benefit from the protections offered by international human rights law. ${ }^{18}$ Of note, the Supreme

15 The CAT findings on the merits are known as "decisions." The HRC findings are called "views."

${ }^{16}$ Audrey Macklin, "Borderline Security" in Ronald Daniels, Patrick Macklem \& Kent Roach, eds, The Security of Freedom: Essays on Canada's Anti-Terrorism Bill (Toronto: University of Toronto Press 2001) 383 .

${ }^{17}$ François Crépeau, Delphine Nakache \& Idil Atak, "International Migration: Security Concerns and Human Rights Standards" (2007) 44:3 Transcultural Psychiatry 311 at 315; see also France Houle \& Noura Karazivan, "Les rapports de relevance juridique entre les ordres législatifs canadien et international” (2008) 1 Revue québécoise de droit constitutionnel 1; Maxime St-Hilaire, "Codification of Human Rights in Canada" (2012) 42 RDUS 505 .

${ }^{18}$ Catherine Dauvergne, "International Human Rights in Canadian Immigration Law: The Case of the Immigration and Refugee Board of Canada" (2012) 19:1 Ind J Global Legal Stud 305 . 
Court of Canada has progressively recognized the role of international law in interpreting the Constitution. ${ }^{19}$ It has held that, like other statutes, the IRPA must be interpreted and applied in a manner that complies with Canada's international obligations, including international human rights instruments to which Canada is a signatory, and that courts should avoid interpretations that would violate these obligations. ${ }^{20}$ Gerald Heckman underlines that the infusion of international human rights law's values and principles into domestic law can only reinforce the institutional and procedural safeguards that surround decision-making in Canadian asylum law. ${ }^{21}$

Researchers in other countries generally agree with the positive impact of individual complaints mechanisms on human rights practices. They have found that enhanced monitoring provided by these mechanisms is reasonably effective in improving non-citizens' human rights in states parties. ${ }^{22}$ It has also been argued that they have the capacity to strengthen democracy through the fostering of public debate ${ }^{23}$ and by allowing non-state actors to play an active role in norm creation and in addressing violations of rights. ${ }^{24}$ Against this background, not only do we fill a knowledge gap on the use of the UN individual complaints mechanisms by non-citizens in Canada, but we also contribute to the extant literature by stressing their role in advancing the rights of non-citizens.

We limit our analysis to the decisions adopted by the UN committees from 2008 to 2018 with a view to providing a thorough discussion of the

${ }_{19}$ Pushpanathan v Canada (Minister of Citizenship and Immigration), [1998] 1 SCR 982.

${ }^{20} R v$ Appulonappa, ${ }_{2015}$ SCC 59, [2015] 3 SCR 754 at para 40; $R v$ Hape, 2007 SCC 26 , [2007] 2 SCR 292 at para 53; Németh v Canada (Justice), 2010 SCC 56, [2010] 3 SCR 281 at para 34 .

${ }^{21}$ Gerald P Heckman, "Securing Procedural Safeguards for Asylum-Seekers in Canadian Law: An Expanding Role for International Human Rights Law?" (2003) 15:2 Intl J of Refugee L 212.

${ }^{22}$ Wade M Cole, "Human Rights as Myth and Ceremony? Re-evaluating the Effectiveness of Human Rights Treaties, 1981-2007" (2012) 117:4 American Journal of Society 1131 at 1163; Susan F Martin \& Rola Abimourched, "Migrant Rights: International Law and National Action" (2009) 47 International Migration 115 at 118 ; Vincent Chetail, "Are Refugee Rights Human Rights? An Unorthodox Questioning of the Relations between Refugee Law and Human Rights Law" in Ruth Rubio-Marin, ed, Human Rights and Immigration, Collected Courses of the Academy of European Law (Oxford: Oxford University Press, 2014) 19 [Chetail, "Are Refugee Rights"]; Vincent Chetail, "Le Comité des Nations Unies contre la torture et l'expulsion des étrangers: dix ans de jurisprudence" (2006) 26:1 RSDIE 63.

${ }^{23}$ Shotaro Hamamoto, "An Undemocratic Guardian of Democracy: International Human Rights Complaint Procedures” (2007) 38:2 Victoria University Wellington L Rev 199 at 212.

${ }^{24}$ Loveday Hodson, "Women's Rights and the Periphery: CEDAW's Optional Protocol" (2014) 25:2 Eur J Intl L 561 at 578. 
relevant decisions and the key findings within the limited space available. As well, Canada's immigration and refugee protection regime went through a major overhaul during this period. The Conservative government (2006-15) introduced the Protecting Canada's Immigration System Act $t^{25}$ and the Balanced Refugee Reform Act, ${ }^{26}$ both of which amended the IRPA. ${ }^{27}$ This legislation contains a number of restrictive measures that apply to immigrants and asylum seekers and include: expedited refugee claim hearings, reduced procedural guarantees, greater use of socio-economic deterrents, and increased immigration detention..$^{28}$ Moreover, it has become easier than before for authorities to remove some non-citizens - notably, long-term permanent residents - from Canada on the ground of serious criminality. ${ }^{29}$ The time period chosen therefore allows us to assess whether and how some of these changes have impacted Canada's compliance with its international human rights obligations under the UN treaties examined. Finally, in line with our goal to identify and critically analyze substantive issues in Canada's immigration decision-making and enforcement, we focus on decisions where Canada has been found to violate rights. The committee decisions finding that rights were not violated are beyond the scope of this article due to the limited space that is available.

After outlining our methodology, we describe the nature of the complaints filed against Canada before the three UN committees studied and discuss their outcomes. In particular, we highlight the importance of representation by legal counsel. We then proceed to discuss the core substantive issue we identified in our analysis of the UN committee decisions - namely, Canada's implementation of the principle of non-refoulement. To this end, we examine four interrelated topics: the ineffective nature of some domestic remedies available to non-citizens to challenge deportation orders against them; the insufficient accommodation by Canada of some non-citizens' vulnerability; the precedence that considerations of state sovereignty and security take over the human rights of migrants; and, finally, Canada's unsatisfactory compliance with the UN committee decisions.

25 Protecting Canada's Immigration System Act, SC 201 2, c 17.

26 Balanced Refugee Reform Act, SC 2010, c 8.

27 Immigration and Refugee Protection Act, SC $2001, \mathrm{c} 27$.

${ }^{28}$ Emily Bates, Jennifer Bond \& David Wiseman, "Troubling Signs: Mapping Access to Justice in Canada's Refugee System Reform” (2016) 47:1 Ottawa L Rev 1; Canadian Association of Refugee Lawyers (CARL), "Reform Proposals for Canada's Inland Refugee Determination System and Other Aspects of the Immigration System” (2016), online: <http://www.carl-acaadr.ca/sites/default/files/CARL\% 2obrief\% 2oFINAL_July2016. pdf>; Idil Atak, Graham Hudson \& Delphine Nakache, "The Securitization of Canada's Refugee System: Reviewing the Unintended Policy Consequences” (2018) 37:1 Refugee Survey Quarterly 1.

${ }^{29}$ IRPA, supra note 6, s 36(1) (a); Faster Removal of Foreign Criminals Act, SC 2013, c 16. 


\section{Methodology}

We conducted a search on the UN's Office of the High Commissioner for Human Rights (OHCHR) treaty bodies search engine to identify individual complaints filed against Canada. The search was filtered by geographic region (Americas; Canada), by committee (CAT, HRC, and CEDAW Committee), and by document type (jurisprudence; follow-up on jurisprudence). As stated, the date range was set from 1 January 2008 to 31 December 2018. This search yielded a total of ninety-seven communications. All communications found were analyzed for subject matter. We noted whether or not the communication was filed by an individual who was not a Canadian citizen and who was alleging a violation of their rights and freedoms that intersects with the IRPA. A total of eighty-one communications were submitted by non-citizens (that is, asylum seekers, undocumented migrants, or permanent residents). The remaining sixteen communications included a multitude of different complaints made by Canadian citizens regarding the alleged violation of, for instance, the principle of non-discrimination or the right to a fair trial. These citizen-lodged complaints were excluded from review. Through further analysis, we found that fourteen communications were discontinued, ${ }^{30}$ three were duplicates, and two were against another country and were erroneously filed in the UN database as complaints against Canada. Consequently, these nineteen communications were excluded from further review. This left us with a dataset of sixty-two communications in total.

We analyzed all sixty-two communications using a table we created that organized the communications according to the following criteria: the treaty the complaint was made under; the articles allegedly violated; legal representation; and admissibility. If the communication was found inadmissible, we analyzed the reasons for such decisions to compare and contrast them and to identify emerging patterns in the facts of the cases and the reasoning of the UN committees in terms of the admissibility review. Likewise, in our analysis of the admissible communications, we paid close attention to the assessment of facts, evidence, and arguments presented by both the government and the complainant(s) in each case. This allowed us to identify common themes and assessment criteria and to compare the reasoning of the committees.

${ }^{30}$ Discontinued communications are those where the committee decides to cease proceedings at the request of the complainant or because of a lack of correspondence between a complainant and the committee. For example, Communication No 597/2014 was discontinued after the committee did not receive complainant comments regarding Canada's observations, despite three reminders being given to the complainant. 


\section{The Nature and Outcome of the Complaints against Canada}

In this section, we describe our findings as to the nature and the outcome of the individual complaints lodged against Canada before the three UN committees. As previously noted, the vast majority of the complaints against Canada between 2008 and 2018 were lodged by non-citizens. To repeat, seventy-six cases $(78.3$ percent $)$ - including the fourteen discontinued ones - out of ninety-seven cases in total were submitted by non-citizens alleging a violation of their rights that intersects with the $I R P A$. Complainants belonged to one of the following groups of noncitizens: (1) asylum seekers whose refugee claims were refused by authorities; (2) undocumented migrants; or (3) permanent residents ordered deported from Canada.

All three of the UN committees are represented in the sixty-two communications lodged by non-citizens. However, the volume of complaints lodged under the ICCPR, the Convention against Torture, and the CEDAW differs greatly. Those made under the ICCPR and the Convention against Torture were comparable; thirty complaints were filed under the former and twenty-nine complaints under the latter. Only three complaints were filed under the CEDAW, indicating that this treaty has been rarely used to lodge a complaint against Canada within the time period analyzed. These figures are consistent with the findings of scholars like Roeland Böker and Wade Cole who have analyzed the use of UN complaints mechanisms in some Western European countries. ${ }^{31}$ They confirm that the CEDAW is rarely used in the Netherlands and Iceland, for instance. ${ }^{32}$ An evaluation of the CEDAW Committee's communications conducted by Loveday Hodson concludes that the CEDAW currently has not been able to blaze a trail in relation to communications of asylum claims. ${ }^{33}$

\section{DECISIONS ON ADMISSIBILITY AND ON THE MERITS}

Of the sixty-two communications lodged by non-citizens, twenty-five were deemed inadmissible. All three $C E D A W$ communications were inadmissible,

${ }^{31}$ Roeland Böker, "Feeling the Heat in Geneva and New York: The Netherlands before the UN Treaty Bodies in Individual Complaint Procedures" in Niels Blokker et al, eds, The Netherlands in Court (Leiden: Brill, 2007) 125; Wade M Cole "Individuals v States: The Correlates of Human Rights Committee Rulings, 1979-2007" (2011) 40:3 Social Sciences Research 985 .

${ }^{32}$ Gudrun Gauksdottir \& Thordis Ingadottir, "Compliance with the Views of the UN Human Rights Committee and the Judgements of the European Court of Human Rights in Iceland" in Asbjørn Eide, Jakob Th Möller \& Ineta Ziemele, eds, Making Peoples Heard: Essays on Human Rights in Honour of Gudmundur Alfredsson (Leiden: Martinus Nijhoff, 2011) 509 at 512 .

${ }^{33}$ Hodson, supra note 24 at 571 . 
as they were found not to be substantiated enough to trigger a review on the merits. Seventeen out of the thirty-seven admissible communications in our sample were filed under the Convention against Torture and twenty under the ICCPR (see Table 1). Most of the communications were inadmissible for two reasons: a complainant's failure to substantiate claims sufficiently and/or their failure to exhaust domestic remedies. We will discuss this point later in the article.

Table 1: Communications by committee and admissibility

\begin{tabular}{lcc}
\hline & Inadmissible & Admissible \\
\hline HRC & 10 & 20 \\
CAT & 12 & 17 \\
CEDAW Committee & 3 & 0 \\
Total & 25 & 37 \\
\hline
\end{tabular}

As to the merits, in nineteen communications, the committees found that Canada had not violated the rights of the complainant, while, in eighteen communications, they found a rights violation. Therefore, in roughly half of all admissible complaints, it was determined that Canada had violated a complainant's rights under the treaty under which the case was filed. The HRC found a rights violation in 65 percent of the admissible communications submitted against Canada by non-citizens. This compares to 29.4 percent of such communications where the CAT found a violation. Thus, within the Canadian context, while both the Convention against Torture and the ICCPR have similar numbers of complaints filed under them and have comparable admissibility rates, complaints filed under the ICCPR are more than twice as likely to be successful than those filed under the Convention against Torture (see Table 2). This discrepancy may be due to the much narrower content focus under the Convention against Torture as compared to the ICCPR. Unlike the former, which specifically deals with the protection against torture or cruel, inhumane, or degrading punishment, the ICCPR sets forth numerous political and civil rights, some of which can be invoked jointly by claimants. Moreover, Article 7 of the ICCPR (which prohibits torture or cruel, inhumane, or degrading punishment) mirrors Article 3 of the Convention against Torture. In other words, in cases where multiple alleged rights violations may be present, including the breach of this prohibition, an individual can reasonably be expected to submit a complaint to the HRC rather than to the CAT because of the broader scope of the ICCPR (see discussion later in this article). For example, in each of two HRC communications, we noticed that the claimants alleged a violation of as many as nine articles, with both communications 
resulting in a violation finding. ${ }^{34}$ One could argue that, in such cases, complaints filed with the HRC would have a higher rate of success than those filed with the CAT. However, other factors may influence the difference found in the success rate of HRC and CAT communications, and it is beyond the scope of our analysis to determine exactly why such a difference is present.

Table 2: Committee decisions on the merits of admissible communications

\begin{tabular}{lccc}
\hline & Non-violation & Violation & Total decisions \\
\hline HRC & 7 & 13 & 20 \\
CAT & 2 & 5 & 17 \\
CEDAW Committee & $\mathrm{O}$ & $\mathrm{O}$ & $\mathrm{O}$ \\
\hline
\end{tabular}

With respect to the allegations made, in the vast majority of the cases, complainants held that their deportation from Canada would amount to a violation of their human rights and, notably, of the principle of non-refoulement. In relation to the CAT, all twenty-nine communications analyzed alleged a violation of Article 3 of the Convention against Torture and, notably, of the non-refoulement principle. The CAT found a violation in five out of seventeen admissible communications (29.4 percent). Before the HRC, all but five communications out of thirty included an allegation of violation of Article 7 of the ICCPR (the prohibition of torture or cruel, inhumane, or degrading punishment). The HRC found a violation of this provision in eight out of thirteen admissible communications (61.5 percent).

These findings are consistent with the extant literature that suggests that these types of cases are regularly submitted to the UN treaty bodies from other countries. ${ }^{35}$ As an illustration, Frans Viljoen has noted that the issue of non-refoulement is particularly present in HRC and CAT communications concerning the Netherlands. ${ }^{36}$ A study by Gudrun

${ }^{34}$ Budlakoti v Canada, Communication No 2264/2013 (4 June 2018) [Budlakoti]; Choudhary v Canada, Communication No 1898/2009 (28 October 2013) [Choudhary].

${ }_{35}$ Alice Edwards, "Peter Pan's Fairies and Genie Bottles: UNHCR, The UN Human Rights Treaty Bodies and 'Complementary Supervision'” in James C Simeon, ed, The UNHCR and the Supervision of International Refugee Law (Cambridge, UK: Cambridge University Press, 2013) 174; Böker, supra note 31; Cole, supra note 22; Frans Viljoen, "Fact-Finding by UN Human Rights Complaints Bodies: Analysis and Suggested Reforms" (2004) 8:1 Max Planck Yearbook of United Nations Law 72.

${ }^{36}$ Viljoen, supra note 35 . 
Gauksdottir and Thordis Ingadottir that examined complaints within the Icelandic context confirms similar findings. ${ }^{37}$ In addition to nonrefoulement, allegations included substantive issues related to the principle of non-discrimination, the right to life, trial rights, and the right to private and family life. As mentioned previously, all of these allegations were made under the $I C C P R .^{38}$

\section{VARIATIONS IN COMPLAINTS OVER THE TEN-YEAR TIME PERIOD ANALYZED}

No significant variation has been observed in the number of complaints made against Canada over the ten-year period under study. We refer here to the date where a complaint is introduced and not to the date a decision was made on a communication. The earliest admissible complaints in our database date back to $2006,{ }^{39}$ where five complaints were lodged by non-citizens against Canada. The figures in the subsequent years were as follows: seven in 2007; six in 2008; seven in 2009; three in 2010; two in 2011; seven in 2012 (including three communications submitted after the entry into force of the 2012 refugee reform); six in 2013 ; ten in 2014; seven in 2015 ; and two in $20166^{40}$ Thus, the implementation of restrictive refugee policies since the entry into force of the Protecting Canada's Immigration System Act and the Balanced Refugee Reform Act does not seem to have had a marked effect on the number of complaints, with the exception of a slight rise in 2014. However, alternative explanations should be taken into account. These include the time that legislative changes take to have a concrete impact on individuals' rights. The prerequisite of exhausting all domestic remedies available before lodging a complaint is another factor that may

${ }^{37}$ Gauksdottir and Ingadottir, supra note 32; see also Menendez, supra note 4; Chetail, "Are Refugee Rights," supra note 22.

38 The most common allegation raised pertains to art 6 , the right to life. Of note, this allegation was often raised in conjunction with art 7 and, thus, very often relates to the principle of non-refoulement. Allegations under art 2 of the ICCPR (prohibition of non-discrimination) were raised in sixteen communications, under art 14 (right to a fair trial) in twelve communications, and under art 23 (right to family life) in thirteen communications. However, these allegations were less successful than those pertaining to non-refoulement. For example, the Human Rights Committee (HRC) found a violation in only five out of thirteen ICCPR communications that did not relate to non-refoulement. It found a violation of art 23 in three cases and of art 6 (right to life) in one case.

${ }^{39}$ In our database, a United Nations (UN) committee takes on average two years to complete the examination of a case.

${ }^{40}$ However, this number may increase, as communications analyzed during the October-November 2018 sessions of the CAT and the HRC have not been published on the UN Treaty Search Database as of February 2019. 
explain why these changes are not more often challenged before the UN committees. Another explanation is the extensive backlogs faced by the UN committees. Specifically, the CAT and the HRC faced backlogs of 170 and 640 communications respectively, as of January 2019. This only includes those communications that have been registered, meaning that the actual number of communications in the backlog is much higher. ${ }^{41}$ It is unclear how many of them include complaints against Canada. However, in $2017,{ }^{42}$ fourteen communications against Canada were registered by the HRC and three in $2018,{ }^{43}$ indicating that at least some of the communications in the backlog include complaints against Canada. In addition, as examined below, some of the controversial legislative changes have already been the object of a number of complaints before the Canadian courts in recent years. Pending domestic court cases could also delay the introduction of a complaint before a UN committee.

\section{THE INTEGRAL ROLE OF LEGAL COUNSEL}

Another feature emerging from our analysis is representation by counsel, which appears to play an important role in the outcome of the communications examined. Of the sixty-two communications analyzed, roughly 84 percent included a complainant who was represented by counsel. Exactly $5^{\circ}$ percent of the communications not represented by counsel were deemed admissible. This finding compares to 61.5 percent of admissible communications where counsel represented the complainant. Using only these numbers, the general takeaway is that the presence of counsel is associated with a more than 10 percent increase in a communication's chance to be deemed admissible by the UN treaty bodies. Similarly, the presence of counsel is associated with a 10 percent increase in the likelihood of a communication being successful on the merits. In $5^{\text {o per- }}$ cent of the admissible communications represented by counsel, the relevant committee found a violation of the treaty under which the complaint was filed, as opposed to 40 percent of the admissible communications not represented by counsel (see Table 3 for a breakdown of the cases by legal representation and outcome).

${ }^{41}$ Mark Limon, "Reform of the UN Human Rights Petition Systems: An Assessment of the UN Human Rights Procedures and Proposals for a Single Integrated System" (2018) Universal Rights Group 1 at 26, online: <https://www.universal-rights.org $>$.

42 "Table of Registered Cases 2017 ," online: United Nations Human Rights Office of the High Commissioner, online: <https://www.ohchr.org $>$.

43 "Table of Registered Cases 2018," online: United Nations Human Rights Office of the High Commissioner, online: <https://www.ohchr.org $>$. 
Table 3: Communications by legal representation and outcome

\begin{tabular}{|c|c|c|c|}
\hline & $\begin{array}{l}\text { Not represented } \\
\text { by counsel }\end{array}$ & $\begin{array}{l}\text { Represented } \\
\text { by counsel }\end{array}$ & $\begin{array}{l}\text { Total number of } \\
\text { communications }(N=62)\end{array}$ \\
\hline \multicolumn{4}{|l|}{ Inadmissible } \\
\hline HRC & 2 & 8 & \\
\hline CAT & 3 & 9 & \\
\hline CEDAW Committee & $\mathrm{O}$ & 3 & \\
\hline Total & 5 & 20 & 25 (inadmissible cases) \\
\hline \multicolumn{4}{|l|}{ Admissible } \\
\hline HRC & 1 & 19 & \\
\hline CAT & 4 & 13 & \\
\hline CEDAW Committee & $\mathrm{O}$ & o & \\
\hline Total & 5 & 32 & 37 (admissible cases) \\
\hline \multicolumn{4}{|l|}{ Non-Violation } \\
\hline HRC & 1 & 6 & \\
\hline CAT & 2 & 10 & \\
\hline CEDAW Committee & $\mathrm{O}$ & $\mathrm{O}$ & \\
\hline Total & 3 & 16 & 19 (non-violations) \\
\hline \multicolumn{4}{|l|}{ Violation } \\
\hline HRC & o & 13 & \\
\hline CAT & 2 & 3 & \\
\hline CEDAW Committee & $\mathrm{O}$ & $\mathrm{O}$ & \\
\hline Total & 2 & 16 & 18 (violations) \\
\hline
\end{tabular}

Representation by legal counsel appears therefore as a factor that enhances complainants' prospect of success before the UN committees. This finding is consistent with research that points to the significant impact that representation by legal counsel has on a positive outcome in asylum proceedings. ${ }^{44}$ We also noticed that some legal counsel make use of the UN individual complaints mechanisms on a regular basis. They seem to have integrated this supranational recourse into their litigation practice. For example, lawyer Stewart Istvanffy acted as counsel in ten of the sixty-two communications analyzed. The same is true for some non-profit organizations. To illustrate, Toussaint $v$ Canada - mentioned in the introduction - was lodged with the support of the Social Rights Advocacy Centre. Both individual lawyers and non-profit organizations have thus been instrumental in mobilizing the UN individual complaints mechanism as an ultimate remedy for their clients or as a form of legal activism

${ }^{44}$ Sean Rehaag, "The Role of Counsel in Canada's Refugee Determination System: An Empirical Assessment" (2011) 49:1 Osgoode Hall LJ 71; Jaya Ramji-Nogales, Andrew Schoenholtz \& Philip G Schrag, "Refugee Roulette: Disparities in Asylum Adjudication" (2007) 6o Stan L Rev 295. 
to challenge allegedly unfair policies and practices. However, the limited number of these actors points to a general lack of awareness of, or interest in, the UN individual complaints mechanisms within Canada's legal community and civil society organizations.

After this overview, we now turn to the substantive issues raised in the UN committees' case law pertaining to Canada's treatment of non-citizens. Our findings highlight several problems, all centred on the principle of non-refoulement. We start with the nature of domestic remedies available to non-citizens to challenge deportation orders.

\section{Effectiveness of Domestic Remedies}

The failure to exhaust domestic remedies is a frequent reason for the inadmissibility of a complaint. Complainants must avail themselves of all domestic remedies available before taking their case to the UN. However, there are exceptions to this rule "where the application of the remedies is unreasonably prolonged or is unlikely to bring effective relief to the person who is the victim of the violation of this Convention." 45 As well, the term "domestic remedies" must be understood as referring primarily to judicial remedies ${ }^{46}$ Although mere doubt about the effectiveness of a domestic remedy does not free a complainant of the obligation to exhaust it, such remedies should be de facto available to the complainant and effective in the given case. ${ }^{47}$ The UN committee decisions shine a light on the nature of some domestic remedies available to non-citizens in Canada, particularly those who are fighting deportation orders. These remedies include: (1) appeals to the Federal Court for judicial review; (2) humanitarian and compassionate (H\&C) applications; (3) pre-removal risk assessments; and (4) administrative deferrals of removal. However, our analysis of committee decisions reveals issues with the effectiveness of these remedies.

Almost all of the cases in our dataset concerned alleged rights violations engendered by deportation orders. The complainants are either asylum seekers whose refugee claims were refused by the IRB, and their family members, or undocumented migrants or permanent residents who have been found inadmissible for "serious criminality." In all of these cases, non-citizens who receive a negative decision from an immigration

${ }^{45}$ OP-CEDAW, supra note 13, art 4(1); Office of the High Commissioner on Human Rights (OHCHR), Fact Sheet No $7 / \operatorname{Rev} 1$, Complaints Procedure, online: $<$ https://www.ohchr. org/Documents/Publications/FactSheet7Rev1 en.pdf>.

${ }^{46}$ Arhuaco v Colombia, Communication No $612 / 1995$ (29 July 1997) at para 5.3.

${ }^{47}$ Convention against Torture, supra note 7, art 22.4(b); Choudhary, supra note 34 at para 8.3; Warsame v Canada, Communication No 1959/2010 (21 July 2011 ) at para 7.4 [Warsame]; A v Canada, Communication No 583/2014 (9 May 2016) at para 6.2 [A v Canada]. 
officer or the IRB ${ }^{48}$ can apply to the Federal Court for judicial review of this decision. ${ }^{49}$ To this end, they must first seek leave or permission of the Federal Court. In their application for leave to apply for judicial review to the Federal Court, individuals are required to raise a "fairly arguable case" or a "serious question to be determined." cial review is granted, the complainant should prove that the first instance decision-maker made an error in law or of jurisdiction. ${ }^{51}$ In A.B. v Canada, the HRC noted that, given the clear domestic legislation and jurisprudence in that regard, this threshold was too high for judicial review by the Federal Court to be considered an effective remedy. ${ }^{52}$ In other decisions, the UN committees confirmed that recourse available to non-citizens at the Federal Court does not pass the test of an effective remedy. In Singh $v$ Canada, the CAT agreed with the complainant that judicial review of the IRB decision denying him refugee status was not an appeal on the merits but, rather, a very narrow review for gross errors of law. ${ }^{53}$ The CAT went on to state that Canada should provide for judicial review of the merits, rather than merely of the reasonableness, of decisions to expel an individual where there are substantial grounds for believing that the person faces a risk of torture..$^{54}$

In a similar vein, $\mathrm{H} \& \mathrm{C}$ applications for permanent residence in Canada are not considered effective remedies by the UN committees because of their discretionary and non-judicial nature. In Kalonzo v Canada, the CAT

48 The Immigration and Refugee Board of Canada (IRB) has four divisions: Refugee Protection Division (RPD), Refugee Appeal Division (RAD), Immigration Division, and Immigration Appeal Division (IAD). The RAD was established in December 2012 by the Protecting Canada's Immigration System Act, supra note 25. Some classes of non-citizens, such as the so-called designated foreign nationals or those who are inadmissible on the grounds of serious criminality do not have access to the RAD or to the IAD.

49 The Federal Court cannot substitute its own decision for the decision made by the immigration officer or the IRB. Instead, the Court will send the case back to Immigration, Refugees and Citizenship Canada or to the IRB for a new decision in the case. IRPA, supra note $6, \mathrm{~s} 72(1)$.

${ }^{50}$ The number of leave applications granted by the Federal Court has remained consistently low over the past decade, impacting the effectiveness of this remedy. To illustrate, 13 percent of applications were granted leave in 2012 and 20 percent of applications in 2017 . Federal Court, Statistics, online: <http://www.fct-cf.gc.ca/ fc_cf_en/Statistics.html>; see also Sean Rehaag, "Judicial Review of Refugee Determinations: The Luck of the Draw?" (2012) Research Report No 9 Comp Research in Law and Political Economics 1.

${ }^{51}$ Federal Courts Act, RSC 1985 , c F-7, s 18.1 (4).

${ }^{52} A B v$ Canada, Communication No 2387/2014 (15 July 2016) at para 7.4 [AB v Canada]; Warsame, supra note 47 at para $7 \cdot 5$.

${ }^{53}$ Singh v Canada, Communication No 319/2007 (30 May 2011) at para 8.8 [Singh].

${ }^{54}$ Committee against Torture, "Conclusions and Recommendations, Canada," Doc CAT/ C/46/D/319/2007 (7 July 2005) at para 5(c); Singh, supra note 53 at para 8.9. 
drew attention to the apparent lack of independence of the civil servants deciding on such a remedy. It observed that, although the right to assistance on humanitarian grounds may be a remedy under the law, such assistance is granted by a minister on purely humanitarian grounds rather than on a legal basis and is thus ex gratia in nature. ${ }^{55}$ In addition, an H\&C application does not stay removal, such that a person could be expelled during consideration of the application..$^{56}$ The length of the H\&C process is another factor that can contribute to its ineffectiveness. In Shakeel v Canada, the committee observed that four years after the complainant's $\mathrm{H} \& \mathrm{C}$ application was filed, it remained unanswered and said that the delay in responding to the application was unreasonable. ${ }^{57}$ Consequently, failure to exhaust this remedy does not constitute an obstacle to the admissibility of the complaint.$^{58}$ Unsurprisingly, judicial review by the Federal Court of an H\&C decision is not considered to be an effective remedy either. ${ }^{59}$

A pre-removal risk assessment (PRRA) is another domestic remedy that the UN committees consistently found ineffective during the past decade. A PRRA is an assessment of the risk a non-citizen would face if removed from Canada. A refused refugee claimant is eligible to file a PRRA application, which is subject to judicial review by the Federal Court. Similarly, a non-citizen who is ordered deported from Canada for criminality can also file a PRRA application. PRRA submissions may only include new evidence of a risk of danger or persecution that arose after rejection of the refugee protection claim or deportation order. An Immigration, Refugees, and Citizenship Canada officer assesses the application and renders a decision. An applicant may request judicial review of a negative PRRA decision. There are two issues with this remedy. First, as noted above, the Federal Court's review is limited to errors of law and procedural flaws. Second, the PRRA application has no suspensive effect — that is, pending any judicial review proceedings or other recourse, applicants who receive a negative PRRA decision can be removed from Canada. In effect, in N.S. v Canada, a case involving the removal of a refused asylum seeker to India, the CAT

${ }^{55}$ Kalonzo v Canada, Communication No 343/2008 (4July 2012 ) at para 8.3 [Kalonzo].

${ }^{56} X$ v Canada, Communication No 2366/2014 (5 November 2015) at paras 8.3, 16 [X v Canada]; Choudhary, supra note 34 at para 8.3; Y $v$ Canada, Communication No 2327/2014 (10 March 2016) [Yv Canada].

57 Shakeel v Canada, Communication No 1881/2009 (24July 2013) at para 7.4 [Shakeel].

${ }^{58} A v$ Canada, supra note 47 at para 6.2; JK v Canada, Communication No 562/2013 (23 November 2015) at para 9.2 [JKv Canada]; see also HRC, "Concluding Observation on the Sixth Periodic Report of Canada," Doc CCPR/C/CAN/CO/6 (13 August 2015 ) at 1.

59 Thuraisamy v Canada, Communication No 1912/2009 (9 July 2013) at para 6.4 [Thuraisamy]. 
highlighted these issues. It remarked that judicial review of a negative PRRA decision is not an effective remedy since this "narrow review for gross errors of law does not involve a review of the merits of the case and does not have suspensive effect." 60 The HRC reached the same conclusion in Thuraisamy $v$ Canada. ${ }^{61}$ What is more - and similar to the leave for judicial review figures - historically, the PRRA acceptance rate has been low: for instance, 2.8 percent in 2013 and 3.1 percent in $2014 .{ }^{62}$ These figures add to the concerns about the PRRA's effectiveness.

Finally, administrative deferral of removal is another recourse deemed ineffective. The HRC has noted that such recourse before the Canada Border Services Agency is temporary, limited to the assessment of new evidence and largely dependent on the discretion of the agency enforcement officer. ${ }^{63}$

The UN committees' findings illuminate the limited nature of effective remedies available to non-citizens challenging a deportation order. This fundamental issue in Canada's immigration and refugee law has been exacerbated by the 2012 legislative changes. ${ }^{64}$ Take the creation of a new class of "designated foreign nationals" (DFNs) ${ }^{65}$ which allows the minister of public safety to designate individuals who arrive in Canada in a group with the help of a smuggler and mandates the detention of DFNs aged sixteen and over. ${ }^{66}$ Not only are DFNs required to prepare their IRB hearing within forty-five days (as opposed to sixty days for most non-DFNs), but they also do not have the right to an automatic stay of removal upon applying for leave for judicial review and can therefore be deported during their application. As well, pursuant to the legislative changes in 2012, the effectiveness of the H\&C applications has become even more questionable since refused asylum claimants can now apply for permanent residence on $\mathrm{H} \& \mathrm{C}$ grounds (section 25 of the IRPA) only one year following their final

${ }^{60}$ NS v Canada, Communication No 582/2014 (1 December 2016) at para 8.2.

61 Thuraisamy, supra note 59 .

${ }^{62}$ Government of Canada, "Evaluation of the Pre-Removal Risk Assessment" (22 April 2016), online: <https://www.canada.ca/en/immigration-refugees-citizenship/corporate/ reports-statistics/evaluations/removal-risk-assessment-program/prra.html>.

${ }^{63}$ Contreras v Canada, Communication No 2613/2015 (27 March 2017) at para 7.3 [Contreras].

${ }^{64}$ On a positive note, one of the changes involved the establishment of the Refugee Appeal Division within the IRB. Rejected claimants can appeal the RPD decision to the RAD of the IRB (IRPA, supra note 6, ss 110 (1), 159.91). The RAD's role is to review the merits of decisions by the RPD, ultimately deciding to confirm the decision, set it aside and substitute its own decision, or refer it back to the RPD for redetermination.

65 Ibid, s 20.1 (2).

${ }^{66}$ Ibid, s 55 . 
IRB determination (or five years following the IRB's final determination in the case of DFNs) (section 25 (1.01) of the IRPA), compared to immediate access to this remedy under the previous system. In addition, claimants are barred from submitting $\mathrm{H} \& \mathrm{C}$ applications while their refugee claim is pending, which was previously allowed.

These are only some of the recent legislative changes affecting non-citizens' access to justice. Although their consistency with Canada's international human rights commitments has not been tested yet by the UN committees, these changes further impede the availability and effectiveness of existing remedies. More than this, though, they considerably heighten the risk of refoulement.

\section{Taking the Vulnerability of Non-Citizens Ordered Deported SERIOUSLY}

The deportation of individuals to places where they may face persecution or a substantial risk of torture or similar abuse is prohibited by both the $I C C P R$ and the Convention against Torture. Before we delve into the details of non-refoulement cases and what they reveal about Canada's compliance with this prohibition, it is worth reiterating the main principles that stand out in the guidelines and jurisprudence of the UN committees. General Comment No. 1 adopted by the CAT in 1997 states that the risk of torture must be assessed on grounds that go beyond mere theory or suspicion. ${ }^{67}$ Although the risk does not have to meet the test of being highly probable, it must be personal and present. To that end, all relevant facts and circumstances must be considered, including the general human rights situation in the complainant's country of origin. However, the existence of a consistent pattern of gross, flagrant, or mass violations of human rights in a country does not as such constitute sufficient grounds for determining that a particular person is in danger of being subjected to torture upon their return to that country. Additional grounds must exist to show that the individual concerned is personally at risk. ${ }^{68}$ Thus, it should be established whether the individual would be personally at a foreseeable and real risk of being subjected to persecution or torture in the country to which they would return. ${ }^{69}$

${ }^{67}$ CAT, "General Comment No 1: Implementation of Article 3 of the Convention in the Context of Article 22 (Refoulement and Communications)," Doc A/53/44 (21 November 1997) at para 6 , annex IX.

${ }^{68}$ AM v France, Communication No 302/2006 (5 May 2010) at para 13.2; SPA v Canada, Communication No 282/2005 (6 December 2006) at para 7.1; Singh, supra note 53 at para 8.2; PSB and TK v Canada, Communication No 505/2012 (13 August 2015) at para $8.4[P S B$ and $T K]$.

${ }^{69}$ TI v Canada, Communication No 333/2007 (15 November 2010); AMA v Switzerland, Communication No 344/2008 (2 November 2010) at para 8.3. 
Before the UN committees, the burden of presenting an arguable case is on the complainant who needs to identify an irregularity in the decision-making process ${ }^{70}$ or any risk factor that the state (in this context, Canadian) authorities failed to take properly into account. ${ }^{71}$ As well, the complainant has to demonstrate that the treatment they received from the state was arbitrary or manifestly erroneous or amounted to a denial of justice. ${ }^{72}$ In line with the principle of subsidiarity, the UN committees give considerable weight to findings of fact that are made by organs of the state party concerned. ${ }^{73}$ Accordingly, it is generally for the organs of a state party to examine the facts and evidence of the case in order to determine whether a relevant risk exists, unless it can be established that the assessment was arbitrary or amounted to a manifest error or denial of justice. ${ }^{74}$ The UN committees do not have the ability to undertake independent fact finding when confronted with contradictory evidence offered by a complainant and a state party ${ }^{75}$ Nevertheless, they are not bound by state party findings and have the power of free assessment of the facts based upon the full set of circumstances in each case. ${ }^{76}$ Hence, the UN committees conduct a review of the facts, of the evidence submitted by the complainant, and of the state authorities' findings in light of the country of origin information available. Whether the state party took into account all of the elements available to evaluate the risk faced by the complainant is another criterion the committees consider, ${ }^{77}$ together with the will and the ability of the state party to protect the individual once deported. ${ }^{78}$

In the cases we examined in which a treaty rights violation was found, the UN committees essentially argued that Canada did not give enough weight to allegations made and to evidence provided by a complainant. For example, in Choudhary $v$ Canada, the complainant claimed that between 2000 and 2002 he was a victim of violent attacks by members of the Sunni extremist group Sipahe-Sahaba in Pakistan and that a fatwa - that is, an

${ }^{70}$ CAT, supra note 67 at para $5 ; A B v$ Canada, supra note $5^{2}$.

$71 X v$ Canada, supra note $5^{6}$ at para 9.5 .

${ }^{72} Y v$ Canada, supra note $5^{6}$ at para 7.6.

73 DY v Sweden, Communication No 463/2011 (16 July 2013) at para 9.4.

${ }^{74}$ CAT, supra note $67 ; Y v$ Canada, supra note 56 at para 10.3 .

75 Steiner, Alston \& Goodman, supra note 4 at 894 .

76 Convention against Torture, supra note 7 , art $22(4)$; PSB and TK, supra note 68 at para 8.4 .

${ }_{77} Y v$ Canada, supra note $5^{6}$ at para 10.4; SS v Canada, Communication No $581 / 2014$ (30 November 2016) at para 7.6; PSB and TK, supra note 68 at para 8.4; see also NDJMD v Canada, Communication No 2487/2014 (8 November 2017); Av Canada, supra note 47 at paras $7 \cdot 4-7 \cdot 5$.

78 RRL v Canada, Communication No 659/2015 (10 August 2017) at para 9.6. 
arrest warrant for blasphemy - was issued against him by this group. Naveed Akram Choudhary's refugee claim was rejected by the IRB because of his failure to establish his identity at the initial stage of the procedure, and he was not given any further opportunity to have his refugee claim assessed, even though his identity was later confirmed. The HRC remarked that further analysis should have been carried out by the IRB in this case. ${ }^{79}$ Drawing attention to the situation prevailing in Pakistan, notably the fact that members of religious minorities, like the complainant, continue to face fierce persecution and that the Pakistani authorities are unable, or unwilling, to protect them, the HRC concluded that due weight was not given to the complainant's allegations.$^{80}$ In another case, the refugee claim of the complainant was rejected by the IRB because of inconsistencies in his statements and a lack of credible evidence in support of his allegations that there was a fatwa issued against him in Pakistan. The HRC concluded that insufficient attention was given to the complainant's allegations about the real risk he might face if deported to Pakistan where no state protection would be offered to him. According to the HRC, Canada had failed to undertake any serious examination of the authenticity of the fatwa against the complainant, and no thorough investigation was conducted with regard to the author of the fatwa. Investigation would have been all the more critical with respect to acts regarded by the police as constituting an offence under Pakistani criminal law (blasphemy law), which incurs the death penalty. Furthermore, as emphasized by the HRC, Canada failed to take into account the uncontested medical reports submitted by the complainant, which pointed to risks for his mental health in the event of a forcible return to Pakistan. ${ }^{81}$

In Pillaiv Canada, another case where the IRB rejected the complainants' refugee claim for lack of credibility, the HRC held that the diagnosis of Ernest Sigman Pillai's post-traumatic stress disorder led the IRB to refrain from questioning him about his earlier alleged torture in detention. The committee contended that further analysis should have been carried out by Canadian authorities who gave insufficient weight to the complainants' allegations of torture and the real risk they might face if deported to their country of origin in the light of the documented prevalence of torture in Sri Lanka. ${ }^{82}$

In the case of Thuraisamy $v$ Canada, an ethnic Tamil from the north of Sri Lanka, who had in the past allegedly been detained on several occasions and tortured by both the army and the Liberation Tigers of Tamil Eelam,

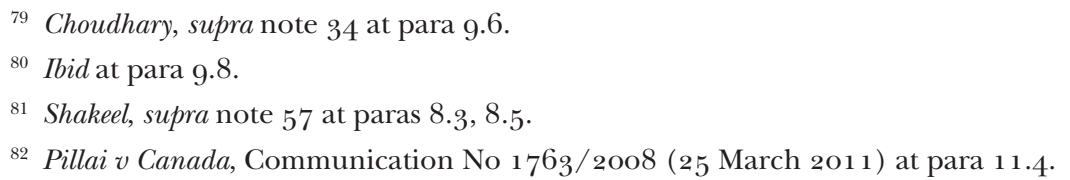


a group listed by Canada as a terrorist organization, the IRB rejected the complainant's refugee claim on the grounds that his statements were inconsistent and the claim lacked credibility. The committee noted that the inconsistencies highlighted by Canada were not directly related to Ganesaratnam Thuraisamy's claim of having been tortured and could not in themselves vitiate the whole credibility of his allegations. In the view of the HRC, the complainant pointed to scars on his chest as evidence of recent torture by the army:

This physical evidence should have been enough for the authorities to request an independent expertise on the possible causes for those scars and their age. ... Indeed, it was for the IRB and [PRRA] officers to dispel any doubts that might have persisted as to the cause of such scarring.... The State party failed to direct an expert opinion as to the cause and age of the scars observed on the author's chest and based its decision to reject the author's asylum claim merely on inconsistencies that are not central to the general allegation faced by the author as an ethnic Tamil from the North of Sri Lanka. ${ }^{83}$

These cases point to the flaws - such as discarding or not taking seriously evidence submitted or risks faced in the case of deportation in Canada's decision-making process. Interestingly, they also suggest that Canadian authorities do not pay enough attention to the hardship faced by some religious and ethnic minorities and the challenges they encounter in terms of state protection. Similarly, gender-based persecution allegations have attracted heightened scrutiny from the UN committees. In J.K. $v$ Canada, which involved a refused homosexual asylum seeker from Uganda, the CAT pointed to Canada's acknowledgement that the situation of lesbian, gay, bisexual, transgender, and intersex (LGBTI) persons in Uganda is problematic. It remarked that the complainant may be at risk of torture or ill-treatment if he is returned to Uganda, taking into account not only his sexual orientation but also his militancy in LGBTI organizations and the fact that he could be detained pursuant to the criminal charges brought against him. ${ }^{84}$ Referring to the evidence provided, including a supporting letter from the Uganda Human Rights Commission, an attestation from the Gay and Lesbian Association in Uganda, and a medical report, the CAT held that the complainant had provided sufficient reliable information for the burden of proof to shift to the state. It brushed off the Canadian government's concerns about the reliability of some evidence, by recalling its jurisprudence that complete accuracy is seldom to be expected from victims of torture.

83 Thuraisamy, supra note 59 at paras 7.5-7.6; Singh, supra note 53 at paras 8.5-8.6.

${ }^{84} \mathrm{JK} v$ Canada, supra note $5^{6}$ at paras $10.4^{-10.5}$. 
In a similar way, in Kaba $v$ Canada, the complainant held that Canada's decision to expel her fifteen-year-old daughter to Guinea would entail a risk of her being subjected to excision by her father and/or members of the family. In the view of the HRC, although female genital mutilation is prohibited by law in Guinea, this legal prohibition is not complied with, meaning that genital mutilation is a common and widespread practice in the country, particularly among women of the Malinke ethnic group to which the complainant's daughter belonged. The committee further remarked that those who practice female genital mutilation do so with impunity, and the family of the girl's father was in favour of this practice being carried out. Also highlighting the context of a strictly patriarchal society in Guinea, the HRC ruled in favour of the complainant. ${ }^{85}$

This decision casts light on the UN committees' assessment that Canada at times fails to accord enough weight to the specific vulnerability of certain groups, such as children. D.T. $v$ Canada is another telling example. In this case, the HRC decided that Canada had failed to give primary consideration to the principle of the best interests of the child. A deportation order was issued against D.T., a refused asylum seeker and a single mother of a seven-year-old child who was a Canadian citizen. The committee said that D.T.'s removal pursued a legitimate objective - namely, the enforcement of immigration law against a person who had no legal status in Canada. However, the complainant's son A.A. suffered from several health conditions that could result in the need for one or several surgeries in the future. In addition, the child had been prescribed daily medication, for which a multidisciplinary intervention plan was developed in his school in Canada, involving special education professionals. ${ }^{86}$ Reminding Canada that in all decisions affecting a child, the child's best interests shall be a primary consideration, the HRC concluded that the issuance of a removal order faced D.T. with the choice of leaving her child behind in Canada or exposing him to a lack of medical and educational support on which he was dependent. What is more, no information had been provided by Canada to indicate that the child had any alternative adult support network in Canada. Given the young age and special needs of the complainant's son, both alternatives confronting the family - the son remaining alone in Canada or returning with the complainant to Nigeria - could not have been deemed in the best interests of the child. The committee emphasized that Canada had not adequately explained why its legitimate objective in upholding its immigration policy should outweigh the best interests of the complainant's child or how such an objective could

${ }^{85}$ Kaba v Canada, Communication No $1465 / 2006$ (25 March 2010) at para 10.2.

${ }^{86}$ DT v Canada, Communication No 2081/2011 (15 July 2016) at paras 7.7-7.8. 
justify the degree of hardship that confronted the family as a result of the decision to remove the complainant. ${ }^{87}$

It is noteworthy that in 1999 , in Baker $v$ Canad ${ }^{88}$ - a case concerning a deportation order against a foreign mother of four Canadian children - the Supreme Court of Canada established that the immigration official exercising discretion in deportation cases was bound to consider the principle of the best interests of the child, expressed in the 1989 Convention on the Rights of the Child. The Court directed decision-makers to look to those values in international human rights law that resonate with the fundamental values of Canadian society in order to identify the relevant considerations demarcating their discretionary decision-making powers. ${ }^{89}$ The D.T. decision shows, however, that twenty years after this landmark judgment, Canadian authorities still tend to overlook basic human rights principles that stem from domestic and international law in the name of state sovereignty interests, notably deterring irregular migration.

This reasoning was clearly spelled out by the decision-makers in Toussaint $v$ Canada, which we mentioned in the introduction and which deals with the right to health care of undocumented migrants in Canada. ${ }^{90}$ Although the case does not raise any refoulement issues, it shows how decision-makers take a harsh stance on undocumented migrants who are perceived to deliberately ignore immigration rules, without consideration of their vulnerability. In this case, Nell Toussaint lawfully entered Canada as a visitor from Grenada. She worked in Canada from 1999 to 2008 without obtaining residency status or permission to work, although she tried to regularize her situation. From 2006 onwards, she suffered from severe health issues, but, in 2009, she was denied health care coverage under the federal government's program of health care for immigrants, called the Interim Federal Health Benefit Program (IFHP), since she was undocumented. She argued that Canada failed to fulfil its positive obligation to protect her right to life, which required provision of emergency and essential health care. On judicial review, the Federal Court found that Nell Toussaint had been deprived of her right to life and security of the person due to her exclusion from the IFHP. However, the Court found that denying financial coverage for health care to persons who have chosen to enter or remain in Canada illegally is consistent with fundamental justice and that the impugned policy was a permissible means to discourage defiance of Canada's immigration laws. The Federal Court of Appeal upheld this decision. Toussaint took the case before the HRC, which concluded that

87 Ibid at para 7.10.

88 Baker v Canada (Minister of Citizenship and Immigration), [1999] 2 SCR 817.

${ }^{89}$ Crépeau, Nakache \& Atak, supra note 17 at 316.

90 Toussaint, supra note 1 at paras $2.3,2.6$. 
Canada had discriminated against her. ${ }^{91}$ The committee held that states cannot make a distinction, for the purposes of respecting and protecting the right to life, between regular and irregular migrants and that, "at a minimum, States parties have the obligation to provide access to existing health-care services that are reasonably available and accessible when lack of access to the health care would expose a person to a reasonably foreseeable risk that can result in loss of life." 92

The D.T. and Toussaint cases demonstrate how state sovereignty and the "legal-illegal migrant" dichotomy continue to be the central principles guiding Canadian case law on non-citizens. ${ }^{93}$ Security is another major criterion for decision makers, especially in cases where non-citizens are excluded on security or criminality grounds.

\section{Non-Refoulement of Foreign Nationals Inadmissible to Canada: A Difficult Balance between Security and Human Rights}

The IRPA sets out grounds upon which a non-citizen can be inadmissible to Canada, including security (section $34(1)$ ), human and international rights violations (section $35(1)$ ), serious criminality and criminality (section $3^{6}$ ), and organized criminality (section 37). Indeed, Canadian legislation provides for exceptions to the principle of non-refoulement on the ground of security. According to subsection 115(2) of the IRPA, the non-refoulement principle

does not apply in the case of a person (a) who is inadmissible on grounds of serious criminality and who constitutes, in the opinion of the Minister, a danger to the public in Canada; or (b) who is inadmissible on grounds of security, violating human or international rights or organized criminality if, in the opinion of the Minister, the person should not be allowed to remain in Canada on the basis of the nature and severity of acts committed or of danger to the security of Canada.

The UN committees have chastised Canada for these exceptions on several occasions during the past decade. Most recently, in its concluding observations on the seventh periodic report of Canada, the CAT expressed

${ }^{91}$ Ibid at paras $11.3-11.4,11.7-11.8$.

${ }^{92}$ Inter-American Court of Human Rights, "Juridical Conditions and Rights of Undocumented Migrants," Advisory Opinion AO-18/o3, 17 September 2003; see also HRC, "Concluding Observations on the Sixth Periodic Report of Canada," Doc CCPR/C/ CAN/CO/6 (13 August 2015) at para 12.

${ }^{93}$ Idil Atak et al, "Migrants in Vulnerable Situations and the Global Compact for Safe Orderly and Regular Migration" (2018) Queen Mary University of London Working Research Paper No 2731. 
concerns with the exceptions to non-refoulement. ${ }^{94}$ This report, along with previous comments by the UN committees, recalled that no justification or extenuating circumstances may be invoked to excuse a violation of a state's non-refoulement obligations, which cannot be overridden by a person's character ${ }^{95}$ or by any threat they allegedly may pose.${ }^{96}$ Canada has never provided reasoning for the continued implementation of exceptions to the non-refoulement principle in its domestic legislation. ${ }^{77}$ And, yet, as shown below, security considerations often tend to prevail over this principle.

In one of the cases where Canada made exception to non-refoulement, the complainant was found inadmissible to Canada for his alleged involvement in serious crime in his country of origin. Jose Contreras claimed that he became a target of the MS-13 gang in El Salvador because of his participation in the investigation of the murder of his brother in 1993, which resulted in the conviction and imprisonment for ten years of three MS-1 3 gang members involved in the murder. The IRB found him inadmissible on security grounds, owing to his membership in the Farabundo Marti National Liberation Front (FMNLF) prior to 1992. Three successive pre-removal risk assessments, upheld by the Federal Court, found that Contreras did not face a personal risk at the hands of the MS-19 gang and that he had failed to rebut the presumption of state protection in El Salvador. The HRC challenged Canada's decision and remarked that, since 1992, the FMNLF had been a legal political party in El Salvador and that Canada did not provide any information proving that the complainant currently represents a threat to national security. ${ }^{98}$ Moreover, the committee held that, throughout the asylum procedure, Canada did not accord weight to various aspects of the information provided by the complainant, including the affidavit of an expert on gang violence in Central America, which concluded that the complainant would be "at extraordinarily high risk of egregious physical harm and death if returned." The HRC went on to state that Canada did not properly consider other elements contained in the reports provided by the complainant in support of his pre-removal risk assessment application, according to which violence by gangs particularly affects victims and witnesses of crimes and that El Salvador would be unable to provide due protection to them. ${ }^{99}$

${ }^{94}$ CAT, "Concluding Observations," Doc CAT/C/CAN/CO/7 (21 December 2018) at para 24 .

95 Ibid.

${ }_{96}$ Contreras, supra note 63 at para 8.4 .

${ }^{97}$ Amnesty International, "Canada: Submission to the United Nations Committee against Torture," 65th Sess, 12 November-7 December 2018, Doc AMR/20/9230/2018 (12 October 2018) at 13 .

98 Contreras, supra note 63 at para 8.4 .

${ }^{99} \mathrm{Ibid}$ at paras 8.9-8.10. 
Similar reasoning was adopted by the HRC in Hamida $v$ Canada, where a refugee claimant from Tunisia, who was a member of the Political Security Section of the Ministry of the Interior from 1991 to 1993, was considered inadmissible to Canada. Canadian authorities held that Mehrez Ben Abde Hamida had been aware that torture was a routine practice of that section but that he had not shown that he had made a serious effort to dissociate himself, or resign, from that section. ${ }^{100}$ Here the HRC did not question Canada's decision to exclude Hamida from refugee protection but, rather, its assessment of the risk he would face in case of deportation to Tunisia. The HRC considered that the complainant had provided substantial evidence of a real and personal risk of his being subjected to ill-treatment on account of his dissent in the Tunisian police, his six-month police detention, the strict administrative surveillance to which he was subjected, and the wanted notice issued against him by the Ministry of the Interior, which mentioned his "escape from administrative surveillance." The committee held that there was a real risk of the complainant being regarded as a political opponent and therefore subjected to torture. This risk was increased, according to the HRC, by the asylum application that he submitted in Canada. ${ }^{101}$

This picture is further complicated where a complainant is found inadmissible for alleged involvement in serious crime, not abroad as in the cases of Contreras and Hamida but, rather, in Canada. In Kalonzo v Canada, the government decided to deport a refused asylum seeker involved in serious criminality in Canada to the Democratic Republic of the Congo. This decision was made despite a moratorium declared by Canada suspending deportations owing to the widespread violence in that country. The CAT rejected Canada's arguments that the moratorium would not apply in Arthur Kasombola Kalonzo's case because of his criminal record. It held that in the spirit of Article 3 of the Convention against Torture, a moratorium on the removal of persons who would be at risk in their country because of widespread violence should apply to everyone without distinction. ${ }^{102}$

In addition, the HRC and CAT jurisprudence shows that, when issuing deportation orders, Canada does not pay enough attention to such factors as a non-citizen complainant's criminal record, including the nature of the crimes committed and whether there were any mitigating factors, as well as the complainant's social and family ties in Canada. A telling example is found in A.H.G. and M.R. $v$ Canada, where the committee ruled in favour of a Jamaican man with severe mental illness although his criminal record made him inadmissible to Canada. The complainant arrived in

\footnotetext{
${ }^{100}$ Hamida v Canada, Communication No 1544/2007 (18 March 2010) at paras 2.4, 8.3.

101 Ibid.

${ }^{102}$ Kalonzo, supra note 55 at para $9 \cdot 5$.
} 
Canada at the age of eighteen, where he lived continuously for thirty-one years. In 2005 , after he was evicted from his apartment, he started living in shelters. Having difficulty complying with his medication regime, he experienced psychotic relapses. In 2006, he was found to be inadmissible on grounds of serious criminality following his conviction for assault with a weapon, for which he received a sentence of one day in jail, in addition to eighty days served as pre-sentence custody. While recognizing Canada's legitimate interest in protecting the general public, the HRC held that the deportation to Jamaica of a mentally ill person in need of special protection who has lived in Canada for most of his life constituted a violation by Canada of its obligations under the ICCPR. The HRC underlined that the complainant's criminal offences were recognized to be related to his mental illness, which had resulted in the abrupt withdrawal of the medical and family support on which a person in his vulnerable position was necessarily dependent. ${ }^{103}$

Similarly, when a non-citizen ordered deported on grounds of serious criminality has family members in Canada, a deportation order may interfere with that person's right to family life. In such cases, the relevant criteria for assessing whether or not the specific interference with family life can be objectively justified are, on the one hand, the state party's reasons for the removal of the person concerned and, on the other hand, the degree of hardship the family and its members would encounter as a consequence of such removal. ${ }^{104}$ Over the past decade, the HRC has dealt with a number of such cases. In addition to the right to family life, the emerging case law emphasizes the principle of inhabitance in Canada and a non-citizen's engagement with a community as key factors of membership of that community. In the jurisprudence of the HRC, these factors increasingly militate against the deportation of a non-citizen from Canada.

Take the case of Jama Warsame, a Somali national who had been a permanent resident in Canada since the age of four before he received a deportation order from Canada for serious criminality. The HRC decided that Warsame, who was convicted of robbery and then of possession of a scheduled substance for the purposes of trafficking, should not be deported since Canada was his "own country" within the meaning of Article 12, paragraph 4 , of the ICCPR ${ }^{105}$ In its decision, the committee took into consideration the strong ties connecting Warsame to Canada, the presence of his

103 AHG and MRv Canada, Communication No 2091/2011 (25 March 2015) at paras 10.3$10.4[A H G$ and $M R]$.

${ }^{104} A B v$ Canada, supra note $5^{2}$ at para 8.7; DT v Canada, supra note 86 at para 7.5 .

${ }^{105}$ ICCPR, supra note 7, art 12.4: "No one shall be arbitrarily deprived of the right to enter his own country." 
family in Canada, the language he speaks, the duration of his stay in the country, and the lack of any ties with Somalia other than, at best, formal nationality. The HRC held that, once deported from Canada, Warsame's right to enter his own country - that is, Canada - would be limited and that this would violate his freedom of movement set forth in Article 12 of the ICCPR. Of note, General Comment No. 27 (1999) on freedom of movement considers that the scope of "his own country" is broader than the concept of "country of his nationality": "It is not limited to nationality in a formal sense, that is, nationality acquired at birth or by conferral; it embraces, at the very least, an individual who, because of his or her special ties to or claims in relation to a given country, cannot be considered to be a mere alien." 106

The HRC reiterated in its subsequent jurisprudence that there are factors other than nationality that may establish close and enduring connections between a person and a country, connections that may be stronger than those of nationality. ${ }^{107}$ To illustrate, Deepan Budlakoti was born in Canada to parents holding Indian diplomatic passports and was later sentenced twice for breaking and entering and for trafficking and possessing firearms and drugs. As a result, he was declared inadmissible to Canada. The minister of public safety also claimed that he was not a Canadian citizen and that, owing to his parents' diplomatic status when he was born, his Canadian passport had been issued in error. The complainant alleged that he believed he was a Canadian citizen by virtue of his having been born in Canada - a belief, he argued, that was confirmed by the fact that he was twice issued a Canadian passport. Taking into account the particular circumstances of the case - including the strong ties connecting the complainant to Canada, the presence of his family in Canada, the language he speaks, the duration of his stay in the country, the confusion regarding his nationality, and the lack of any ties to India other than, at best, formal nationality - the HRC noted that Budlakoti had established that Canada is his own country within the meaning of Article 12(4) of the ICCPR. ${ }^{108}$ According to the committee, although the complainant had two convictions dating from 2009 and 2010 , these convictions were not for violent offences and he had not reoffended since his release. It therefore concluded that the interference with Budlakoti's rights under Article 12 (4) would be disproportionate to the stated legitimate aim of preventing the commission of further crimes. ${ }^{109}$

${ }^{106}$ HRC, "CCPR General Comment No 27: Article 12 (Freedom of Movement)," Doc CCPR/C/21/Rev 1/Add/9 (2 November 1999) at para 20; Warsame, supra note 47 at para 9.2.

107 Warsame, supra note 47 at para 8.4.

108 Budlakoti, supra note 34 at para $9 \cdot 3$.

109 Ibid at para 9.4. 
In a similar way, the HRC held that a deportation order on grounds of serious criminality against a Haitian national who had been a permanent resident since the age of two constituted interference in his family life. The complainant, who had been sentenced to thirty-three months' imprisonment for robbery with violence, considered himself to be a Canadian citizen, and it was only on his arrest that he discovered that he did not have Canadian nationality. The HRC noted that this interference had a legitimate purpose - namely, the prevention of criminal offences, but it ruled in favour of the complainant, noting that he had only a single previous conviction, he had lived all his conscious life in Canada, all his close relatives and his girlfriend lived there, and he had no ties to his country of origin and did not have family there. ${ }^{110}$

By contrast, in A.B. $v$ Canada, the HRC ruled that the interference with the complainant's family life, while significant, would not be disproportionate to the legitimate aim of preventing the commission of further crimes and protecting the public. In this case, A.B., a refugee from Somalia, was considered to be a danger to the Canadian public due to "serious criminality." In addition to his criminal record, which started at the age of nineteen and had continued for over thirteen years, totalling twelve criminal convictions including for offences of a violent nature and punishable by long prison terms, the committee also took into consideration the weakness of the complainant's family ties in Canada as well as his capacity for integration in his country of origin. The HRC stated that A.B. lived in Somalia until the age of eleven; he spoke Somali, albeit with difficulty; and he was a member of a majority clan. It therefore concluded that A.B.'s deportation to Somalia, if implemented with due account of the ongoing need to assess the security situation in Mogadishu and southern and central Somalia, including for so-called Western returnees with limited family and clan support, would not constitute a violation of his rights under the ICCPR. ${ }^{111}$ This decision points to the case-by-case analysis conducted by the UN committees, which consider recidivism and the nature of serious crime committed by non-citizens as aggravating factors in their assessment. In this case, however, it is not clear how Canada would monitor A.B.'s situation once in Somalia. The absence of any follow-up mechanisms in such situations renders this safeguard hypothetical. Ironically, in the past, the committees expressed concerns that Canada did not provide any examples of post-return monitoring arrangements between Canada and the receiving states. ${ }^{112}$

${ }^{110}$ Dauphin v Canada, Communication No $1792 / 2008$ (28 July 2009) at para 8.4.

${ }_{111}$ AB v Canada, supra note 52 at paras 8.8-8.10.

112 CAT, "Concluding Observations on the Seventh Periodic Report of Canada," Doc $\mathrm{CAT} / \mathrm{C} / \mathrm{CAN} / \mathrm{CO} / 7$ (21 December 2018) at para 28. 
The cases we have examined in this section underscore the urgent need for Canadian authorities to adopt a principled position with regard to the non-refoulement requirement. In particular, IRPA subsection $115(2)$ exceptions are at odds with Canada's obligations under international human rights law, which, as stressed in Contreras, afford absolute protection against deportation to torture or persecution to anyone in the territory of the state party, regardless of the person's character or the danger the person may pose to society. ${ }^{113}$ A legislative change is all the more necessary since individuals who are declared inadmissible under sections 34,35 , and 37 of the IRPA have no access to $\mathrm{H} \& \mathrm{C}$ assessment or to the Immigration Appeal Division of the IRB to appeal removal orders. ${ }^{114}$ With the legislative changes made in 2012 and 2013, it has become easier than before for authorities to remove some non-citizens from Canada on the ground of serious criminality. As noted by the Canadian Association of Refugee Lawyers:

In the 2012 amendments to the IRPA, ... anyone who falls within the definition of serious criminality (for having been convicted in or outside of Canada of an offence punishable in Canada by a maximum term of imprisonment of at least 1o years) can be barred from access to the Refugee Protection Division (RPD) of the IRB. [These amendments] removed the requirement for a sentence of at least two years for in-Canada convictions, or a danger opinion for convictions outside Canada. These changes dramatically increased the number of claimants who were denied access to the RPD as ineligible. ${ }^{115}$

As well, long-term residents in Canada can be found inadmissible for "serious criminality" and subject to removal without consideration of humanitarian factors if they have been convicted of an offence for which a term of imprisonment of more than six months has been imposed. Before these changes, the "serious criminality" threshold was two years. ${ }^{116}$ As it was, the exceptions to non-refoulement incorporated into Canada's immigration law put non-citizens at risk of torture or persecution upon deportation from Canada. The 2012 legislative changes further exacerbate this risk by redefining "serious criminality" and removing protections previously available to non-citizens.

113 Ibid at para 24

${ }^{114}$ Section 64 of IRPA, supra note 6 , states that no appeal may be made to the IAD by a foreign national if the foreign national has been found to be inadmissible on grounds of security, violating human or international rights, serious criminality, or organized criminality.

115 CARL, supra note 28 at 9 .

116 IRPA, supra note 6, s 36(1) (a); Faster Removal of Foreign Criminals Act, SC 2013 , c 16. 


\section{Canada's Non-Compliance With the UN Committee Decisions}

This brings us to a discussion of Canada's compliance with the UN committee decisions. The cases we have examined point to two issues in this regard. The first one pertains to interim measures whereby the HRC and the CAT call upon a state party to suspend any action while the communication is being considered by either committee. Canadian authorities have not always complied with the interim measures asking Canada not to deport a complainant to their country of origin. ${ }^{17}$ An extension of the non-refoulement principle, interim measures are essential to the effectiveness of the UN individual complaints mechanisms. We identified three cases in our dataset where Canada did not act in accordance with an interim measure, sending the complainant to possible persecution or another life-threatening situation. In the case of a complainant from Jamaica who was forcibly returned to that country, Canada claimed that the interim measure request was only received after the plane taking the complainant to Jamaica had taken off and that it was not appropriate for the committee to issue interim measures in that case. In response, the HRC expressed its regrets that Canada did not consider the possibility of returning the complainant to Canada. ${ }^{118}$ Canada also removed complainants to India ${ }^{119}$ and to Rwanda ${ }^{120}$ notwithstanding the interim measures issued. ${ }^{121}$ Through this behaviour, Canada may have wanted to signal that the interim measures could be overridden where public security was at stake. Nevertheless, such a position violates international law and sets a regrettable example for the rest of the world. As a result, Canada has been repeatedly reminded by the UN committees of the mandatory nature of interim measures and called upon to respect in every instance the requests for such measures since the failure to do so might undermine Canada's commitment to the UN treaty concerned. ${ }^{122}$

Second, Canada has been criticized for its lack of diligence in giving effect to the UN committees' decisions. The ICCPR and the Convention against

${ }^{117}$ Human Rights Committee's Rules of Procedure, Doc CCPR/C/3/Rev.1 1 (9 January 2019), Rule 92.

118 AHG and MR, supra note 103 at para 8.

119 PSB and TK, supra note 68.

${ }^{120}$ LM v Canada, Communication No 488/2012 (11 May 2018) at para 11.8.

${ }^{121}$ See also Mugesera v Canada, Communication No 488/2012 (23 April 2018), in which the CAT found a violation of art 22 due to non-respect of the interim measures request.

122 CAT, "Concluding Observations," Doc CAT/C/CO/6 (25 June 2012) at para 10; CAT, "Concluding Observations," Doc CAT/C/CR/34/CAN (7 July 2005) at para 4(f); CAT, "Concluding Observations," Doc CAT/C/CAN/CO/7 (21 December 2018) at paras $26-27$. 
Torture do not include any provision setting forth the precise legal effect of these decisions. There is no provision to indicate that they are binding. ${ }^{123}$ That said, under the UN individual complaints mechanisms, a state party undertakes to cooperate with the relevant committee in good faith in applying and giving full effect to the procedure of individual complaints. ${ }^{124}$ When a violation of a treaty obligation is found, a follow-up procedure is implemented whereby the state is required to report within a specific time period about the measures it takes to give effect to a decision. The UN committees have the authority to ascertain whether the measures taken are satisfactory. A state can also be invited to take action, including reviewing its national legislation to ensure similar violations do not occur in the future.

Given the traditional dualist account of the role of international law within Canada's legal system, the implementation of international norms and decisions remains a challenge. Although the Supreme Court of Canada has consistently held that the IRPA must be interpreted and applied in a manner that complies with Canada's international obligations, including "international human rights instruments to which Canada is signatory," it is also of the opinion that Parliament intended such instruments to be used as persuasive and contextual factors in the interpretation and application of the IRPA and not as determinative. ${ }^{125}$ Accordingly, while Canada usually takes the position that "Canadian officials will review the final [UN committee] views carefully and give serious consideration to the recommendations," authorities also tend to brush off the criticisms by holding that treaty bodies' final views, requests, and recommendations are not legally binding. ${ }^{126}$ As a result, on several occasions, the HRC has expressed concerns about Canada's reluctance to comply with all of its decisions and called upon Canada "to take necessary measures to establish mechanisms and appropriate procedures to give full effect to the

123 Steiner, Alston \& Goodman, supra note 4 at 892.

${ }^{124}$ See e.g. Convention against Torture, supra note 7, art 22.

${ }^{125}$ De Guzman v Canada (Minister for Citizenship and Immigration), [2006] 3 FCR 655 (Fed CA), leave to appeal denied, [2006] FC 31333 (SCC). Those provisions of the international treaties ratified by Canada but not incorporated into domestic law cannot be invoked independently as the basis for a legal claim in courts other than through domestic legal instruments. In its concluding observations on Canada, the CAT pleaded in favour of the incorporation of the convention into Canadian law. It remarked that this "would not only be of a symbolic nature, but ... it would strengthen the protection of persons allowing them to invoke the provisions of the Convention directly before the courts." CAT, "Concluding Observations of the CAT on Canada, Consideration of Reports Submitted by States Parties under Article 19 of the Convention," Doc CAT/C/CAN/CO/6 (25 June 2012 ) at para 8.

${ }^{126}$ International Complaints, online: Government of Canada <https://www.canada.ca $>$ 
Committee's decisions so as to guarantee an effective remedy when there has been a violation of the Covenant." 127

A telling example is the above-mentioned Warsame case where Canada deported the complainant despite the HRC's finding that this would amount to a violation of his rights under the ICCPR. In the aforementioned A.H.G. and M.R. $v$ Canada case, the HRC chastised Canada for failing to provide a Jamaican man with severe mental health issues with an effective remedy, including compensation and allowing him to return to Canada. ${ }^{128}$ In a similar way, in Toussaint, Canadian authorities ignored the HRG's request to ensure that undocumented migrants have access to essential health care to prevent a reasonably foreseeable risk that can result in loss of life. ${ }^{129}$ Moreover, in some cases, Canada has considerably delayed the implementation of the UN treaty body's recommendations. For example, authorities took more than twenty years to comply with a 1994 CAT decision to cancel a deportation order against a complainant from Pakistan. It was not until 2017 that Canada agreed to grant the person a temporary resident permit and a path to permanent residency. ${ }^{130}$

\section{Conclusion}

In the past decade, the vast majority of individual complaints lodged against Canada before the UN treaty bodies concerned the condition of non-citizens. Undocumented migrants, refused asylum seekers, and Canadian permanent residents ordered deported on the grounds of serious criminality made up the bulk of complainants. Generally, these individuals challenged deportation orders issued against them, alleging a risk of refoulement and, in some cases, other human rights violations. Both the HRC and the CAT have been used as supranational recourse by noncitizens, whereas the number of individual communications before the CEDAW Committee has remained very limited. The annual breakdown of the individual complaints does not point to a significant increase after the

${ }^{127}$ HRC, "Concluding Observations on the $6^{\text {th }}$ Periodic Report of Canada," Doc CCPR/C/ $\mathrm{CAN} / \mathrm{CO} / 6(13$ August 2015) at para 5 .

${ }^{128}$ HRC, "Follow-Up Progress Report on Individual Communications Adopted by the Committee at its 118 th Session (19 October-6 November 2015)," Doc CCPR/C/118/3 (1 August 2016) at 13 .

129 Toussaint, supra note 1 at para 13; HRC, "Report of the Follow-Up to the Concluding Observations of the HRC," Doc CCPR/C/123/2 (11 December 2018) at 13.

${ }^{130}$ CAT, "Follow-Up Report on Decisions Relating to Communications Submitted under Article 22 of the Convention," Doc CAT/C/6o/4 (20 October 2017) at 2; CAT, "Periodic Report of the Rapporteur for Follow-Up to Decisions on Complaints Submitted under Article 22 of the Convention," Doc CAT/C/56/2 (22 December 2015) at 8; see also CAT, "Follow-Up Report on Decisions Relating to Communications Submitted under Article 22 of the Convention," Doc CAT/C/6o/4 (20 October 2017) at 2. 
entry into force, in 2012, of the immigration and refugee protection legislative changes. However, it is likely that there will be further complaints in the future given the time it often takes for the full effect of legislative changes to be seen and the significant backlog of communications within the UN committees. More complaints may also be expected in the future since a small, core group of Canadian legal counsel has continually been active in taking cases to the HRC and the CAT. Unsurprisingly, we found that legal representation enhances the chances of success of a complaint's outcome. Although the UN individual complaints mechanisms are still far from being widely used by legal counsel and civil society organizations, they emerge as tools of strategic litigation and shed light on problematic issues in Canada's immigration and refugee protection system.

The core issue that arises from the UN committees' jurisprudence concerns Canada's difficult compliance with the non-refoulement principle. We have illuminated a number of interrelated problems in this regard. The first one pertains to the effectiveness of the domestic remedies available to non-citizens to successfully challenge deportation orders against them. The HRC and the CAT case law clearly establish that remedies such as judicial review by the Federal Court and H\&C applications are not effective. Although not yet reflected in the UN case law, this issue may have been exacerbated by some of the 2012 changes in immigration and refugee protection, which further restrict remedies available to non-citizens, thereby increasing the risk of refoulement.

Second, the jurisprudence of the UN treaty bodies points to several loopholes in Canada's immigration and refugee protection system that further heighten this risk. In particular, Canadian decision-makers do not give due weight to allegations and to evidence presented by vulnerable complainants, such as members of religious minorities and those at risk of facing gender-based persecution. In a similar vein, the case law shows that the child's best interests are still not a primary consideration in all decisions affecting a child. When dealing with non-citizens, Canadian authorities clearly prioritize aims such as the deterrence of irregular migration, the prevention of criminal offences, and the protection of the general public. Such aims tend to outweigh the protection of non-citizens' human rights. The current approach relegates to the backburner Canada's international obligations under the UN human rights treaties. As well, for the same reasons, Canada is not always inclined to comply with recommendations by the UN treaty bodies.

The last problem we have highlighted concerns the exceptions that Canada's domestic law applies to the non-refoulement principle. Both the CAT and the HRC allow no derogation from this principle, which is an obligation that cannot be overridden by states. Nevertheless, there have been cases where Canada has disregarded this obligation and deported non-citizens deemed to be a risk to Canada's security. These cases 
demonstrate Canada's lax implementation of the non-refoulement principle and the need to take a humanitarian approach in bringing human rights obligations and national security into balance.

The case law overview we have provided also highlights the principles and methods used by the UN committees when they assess different elements of an individual communication. In this case-by-case analysis, the specific circumstances of each case play a significant role in the decision-making process. So does the evidence presented by complainants and the state in support of their claims. The UN committees have shown remarkable capacity to critically analyze, and challenge, the findings and the reasoning of national authorities. In several cases, they have held Canada to account for non-compliance with its human rights obligations. The UN committees play a vital role in the protection of non-citizens. Canada needs to take these committees' decisions seriously. 